\title{
Can Building Codes Stop the Vicious Cycle of Recurrent Disaster?
}

\author{
América Bendito ${ }^{1, *}$ and Arnaldo Guitérrez ${ }^{2}$ \\ ${ }^{1}$ Universidad de Los Andes, Mérida-Venezuela \\ ${ }^{2}$ Universidad Católica Andres Bello, Caracas, Venezuela
}

\begin{abstract}
Despite advances and large amounts of money invested in science and technology to reduce disasters, many communities in developed and developing countries are still facing challenges to disaster reduction. Although we recognize the diversity of risk vulnerabilities, the focus of this paper will be on what we consider a fundamental vulnerability in urban and rural environments, namely, nonexistent or outdated building codes. We will review for different countries and contexts, the pre- and post-disaster building performance and building codes to understand what the main problems are, what we could be doing better, and what we can do to stop the vicious cycle of recurrent disasters.
\end{abstract}

Keywords: Building codes, capacity building, performance, resilence, risk, sustainability.

\section{INTRODUCTION}

Media reports are filled with images of catastrophic natural events which suggests the earth is now more dangerous and active place. Despite advances and investments in science and technology in disaster resilience, many communities in developed and developing countries are still facing challenges to disaster reduction [1].

United Nations Secretary-General Ban Ki-moon urged the worldwide community to adopt drastic measures to mitigate and adapt against the effects of climate change [2]. Similarly, the ten-year Hyogo Framework for Action period, that will conclude at the end of 2015, highlights that disaster risk reduction is the first and most urgent step in adapting to climate change. Furthermore, this priority is also recognized in the successor agreement to the Kyoto Protocol [3]. The impacts of natural disasters and climate change are particularly severe among the most vulnerable social groups (people segregated from the recognized economy of the city, with lack of entitlements and lack of fundamental services, and people living in marginal land exposed to climatic events) [4].

Many seismologists have said that "earthquakes don't kill people, buildings do". Of the two components of risk, hazard and vulnerability, we can only act on the second one; hence the need to concentrate efforts on vulnerability, as a dynamic condition, which is a common goal shared by disaster risk reduction and climate change adaptation $[5,6]$. We need to understand and integrate the local context (society, economics, politics, geography, climate and hazard) during the development of climate change adaptation interventions [7].

Although we recognize the diverse nature of risk vulnerabilities, the focus of this paper will be on what we consider

*Address correspondence to this author at the Universidad de Los Andes, Mérida-Venezuela; Tel: +582742441532; Fax: +582742441532;

E-mail: americabendito@gmail.com a fundamental vulnerability in urban and rural environments, namely, outdated building codes or the non-existence of any codes at all. In this study, we will use country experiences on building performance and building codes to illustrate and raise awareness about the need to develop safer construction standards as an effective way to mitigate the destructive impacts of natural disasters such as earthquakes, floods and hurricanes. We will then highlight the importance of developing user-friendly capacity building tools to improve the communication and understanding of key concepts and principles embedded in building codes in order to enhance the capacities and skills of local engineers, contractors, and construction workers to design and construct safe structures, and to spread this knowledge widely in order to break the vicious cycle of recurrent disaster.

\section{PERFORMANCE, RISK, RESILIENCE, AND SUSTAINABILITY}

Traditional seismic building codes, conceptually based on the concept of ductility and with the design philosophy to safeguard loss of life, are designed to make it extremely unlikely, but not impossible, that built structures following such codes will collapse. Lessons learned from past disasters indicate that new approaches and philosophies should move towards building codes that integrate four important conditions that define structural systems and infrastructure: performance, risk, resilience and sustainability. Taking these four conditions into account, we can improve our capabilities for analysis, design, construction and operation, thus fulfilling the user requirements and commitment that our engineering profession has to society [8].

\subsection{Performance-based Design}

Performance-based earthquake engineering has the intention to explain the seismic performance of a structure using scales that could be used instantly by engineers and other stakeholders [9]. A design based on performance can de- 


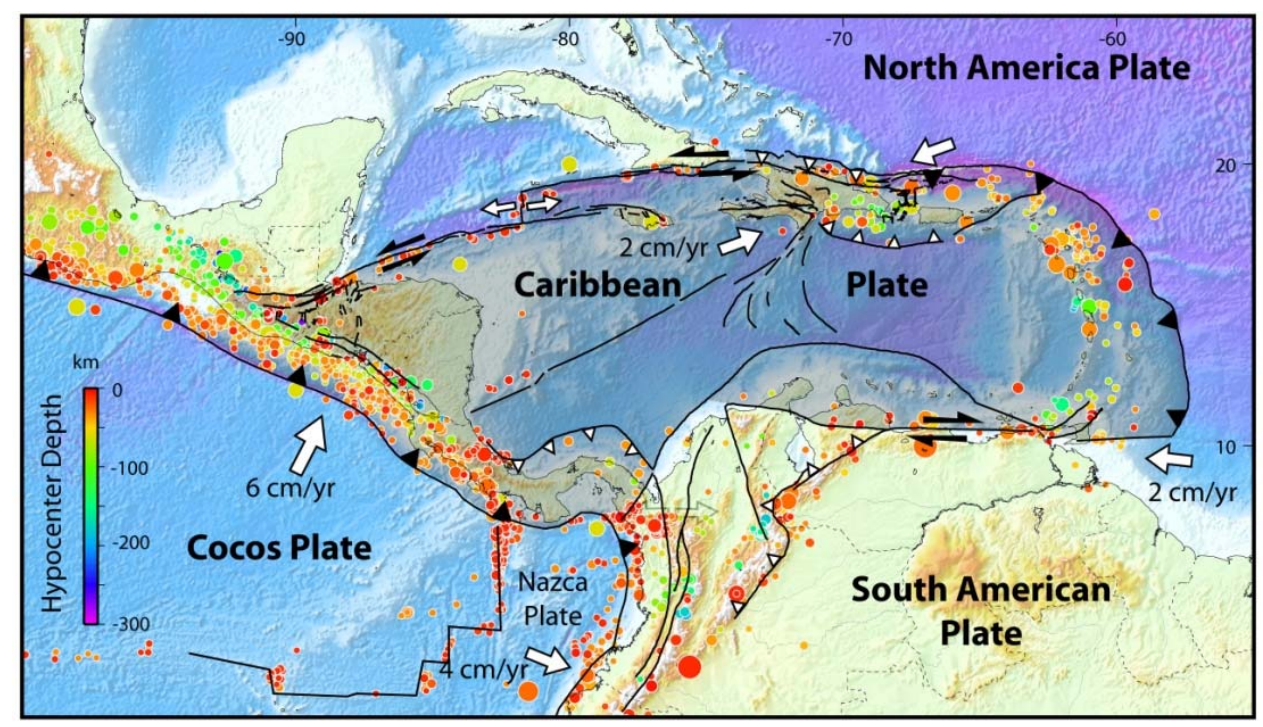

Fig. (1). The position of the Cocos, Nazca, South American and Caribbean Plates.

http://sciencythoughts.blogpot.com/2012/03/understanding-subduction-zone-beneath.html.

scribe what are the limit states and performance levels that are needed for different types of events and structures. Futher, it can manage the latent hazards by the correct control of the damage and losses [8].

In terms of human and economic losses, earthquakes are one of the biggest risks in Venezuela. The current Venezuelan seismic design codes for buildings (COVENIN 1756:2001) is conceptually based only on one performance level: the inelastic behavior of structural resisting elements, when subjected to the effect of ground motion earthquakes with expected low probability of occurrence $(10 \%$ probability of occurrence in 50 years). The current seismic hazard map was incorporated in the Venezuelan code 16 years ago. In order to refine this map and add greater accuracy in building codes, a new and updated Probabilistic Seismic Hazard Analysis (PSHA) was developed for western Venezuela, to be able to include more data about seismotectonic information, especially including adjacent areas of the region, a larger number of attenuation relationships taking into account the type of faulting, the rock type, near fault effects, and more instrumental seismicity [10].

Venezuela is a country with $912,050 \mathrm{~km}^{2}$ of surface area and located in the northern part of South America, bounded on the north by the Caribbean Sea and the Atlantic Ocean, with Brazil to the south, Guyana to the east and Colombia to the west [11]. Seismicity is generated because the country is located between the South American and Caribbean plates that "consists of compressive, extensional and strike-slip tectonic regimes and its location is under current debate". [12-14] (Fig. 1). The more important seismic events have been related to the Bocono fault that extends along the west of Venezuela (Venezuelan Andes region). Even though large earthquakes have occurred in this region, the seismicity is characterized by a high rate of events of magnitude between M3 and M5. One of the most destructive occurred on 26 March 1812, with an estimated magnitude of M7.3; which caused damage and casualties all over the country and also cause damages in other countries as Saint Vincent and Jamaica [12].
The current seismic hazard map of the Venezuelan seismic design codes for buildings (COVENIN 1756:2001) divides the country into seven seismic zones. The hazard in these zones varies from design peak ground acceleration (PGA) of $0.10 \mathrm{~g}$ in zone 1 at rock sites (low) to $0.40 \mathrm{~g}$ in zone 7 (very high), associated with the performance level that estimates a probability of exceedance of $10 \%$ in 50 years. Mérida State is placed in seismic zone 5 high hazard zone with an estimated PGA of $0.30 \mathrm{~g}$.

The PSHA for western Venezuela compares the seismic hazard curves for the principal cities of western Venezuela (Fig. 2). While the values given by the current code for each city are generally close to the values developed by the PSHA. There are noticeable exceptions in Mérida and Trujillo, where the model predicts accelerations greater than the code (e.g. $0.37 \mathrm{~g}$ as against $0.30 \mathrm{~g}$ and $0.43 \mathrm{~g}$ as against $0.30 \mathrm{~g}$ respectively). Mérida and Trujillo have the highest seismic hazard in the region, probably as a result of being located near the most active sections of the Boconó fault. In the case of Coro, the code predicts a PGA greater than the model: $0.20 \mathrm{~g}$ as against $0.13 \mathrm{~g}$. It is considered important that an updated PSHA should be carried out for the rest of Venezuela so that the current Venezuelan seismic design codes for buildings (COVENIN 1756:2001) includes a new seismic hazard map for the whole country.

The PGA values for the main cities of western Venezuela for four different earthquake design levels are shown in Table 1. PGA values should be developed for different performance levels throughout the country, in order to produce hazard maps for the country, for each of the different design levels according to performance-based design methodology and engineers be able to give better communication to clients for different performance expectations [15].

It seems prudent and preventative to evaluate the effect of disasters associated with return periods of 2500 years, usually long-term, and distant alluvium deposits, in order to quantify effects observed in earthquakes as those in Turkey (1970), Romania (1979), and Mexico City (1985). On this specific issue [16] published an updated global ground 

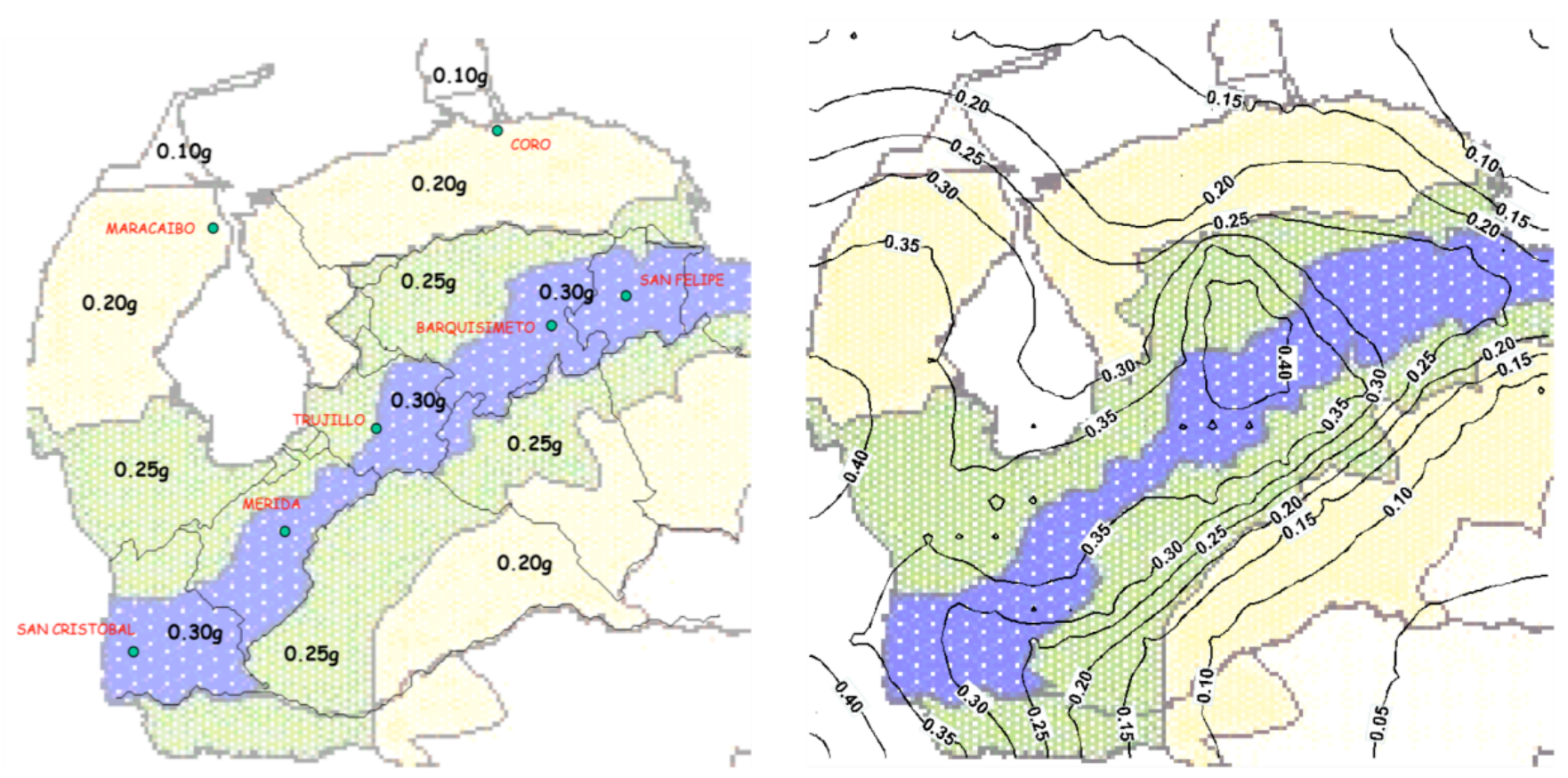

Fig. (2). Values of the current seismic hazard map (left). Values of the new seismic hazard map proposed (right). Both maps for western Venezuela with a $10 \%$ probability of occurrence in 50 years. Source: [10].

Table 1. PGA values for the main cities of western Venezuela for four different earthquake design level [10].

\begin{tabular}{|c|c|c|c|c|c|c|c|}
\hline Earthquake Design Level & \multicolumn{7}{|c|}{ Peak Ground Acceleration (PGA) values (g) } \\
\hline Return Periods (years) & Mérida & San Cristobal & Trujillo & Barquisimeto & San Felipe & Coro & Maracaibo \\
\hline \hline 43 & 0.15 & 0.12 & 0.19 & 0.11 & 0.10 & 0.05 & 0.086 \\
\hline 72 & 0.19 & 0.15 & 0.23 & 0.14 & 0.13 & 0.07 & 0.12 \\
\hline 475 & 0.37 & 0.30 & 0.43 & 0.28 & 0.27 & 0.13 & 0.28 \\
\hline 970 & 0.46 & 0.38 & 0.52 & 0.35 & 0.35 & 0.16 \\
\hline
\end{tabular}

motion data. This database, confirmed statistically, that even from a long distance to the epicenter of large earthquakes, the amplitude of the base rock accelerations was only a few hundredths of gravity, and that the presence of ancient lakes, recent alluvium deposits, or other subsoil conditions with shear-wave propagation velocities lower than 150 to 200 $\mathrm{m} / \mathrm{sec}$, could generate significant amplifications in the PGA, for low frequency ranges with increases in the corresponding spectral values [17].

The current edition of ASCE/SEI 7-10 Minimum Design Loads for Buildings and Other Structures has replaced the uniform-hazard ground motion used in ASCE 7-05 with the risk-targeted ground motion by switching from a $2 \%$ in 50 year hazard level to a $1 \%$ in 50 -year collapse risk target. "The probabilistic portions of the maximum considered earthquake (MCE) ground motion maps in ASCE 7-05 provide ground motion values that have a 2 percent probability of being exceeded in 50 years. While this approach provides for a uniform likelihood (except in deterministic areas) that the ground motion would not be exceeded, it does not provide for a uniform probability of failure for structures designed for that ground motion. The risk-targeted maximum considered earthquake (MCE) ground motion is designated $\mathrm{MCE}_{\mathrm{R}}$ ground motion" [16].

The practical implications includes improved characterization of design spectra for different local subsoil conditions. The selection for 'rare' events with a 2500 year of return period does not change the design criteria of $10 \%$ of exceedance in 50 years that was agreed over 30 years ago. The design earthquake ground motion is based on $2 / 3$ of $\mathrm{MCE}_{\mathrm{R}}$ ground motion for consistency with previous editions of the standard. "In the general procedure, seismic design values are computed from mapped values of the spectral response acceleration at short periods $(0.2 \mathrm{~s}), \mathrm{Ss}$, and at $1 \mathrm{~s}, \mathrm{~S}_{1}$, for Class $\mathrm{B}$ sites and $5 \%$ of critical damping. These Ss and S1 values may be obtained directly from figures in chapter 22 of the ASCE/SEI 7-10. However, these maps themselves do not permit precise determination of Ss and $S_{1}$ values, especially in high seismic regions, so the mapped values may be obtained directly from the USGS website: http://earthquake. usgs.gov/designmaps" [16].

"In regions of high seismicity, the seismic hazard is typically controlled by large magnitude events occurring on a 


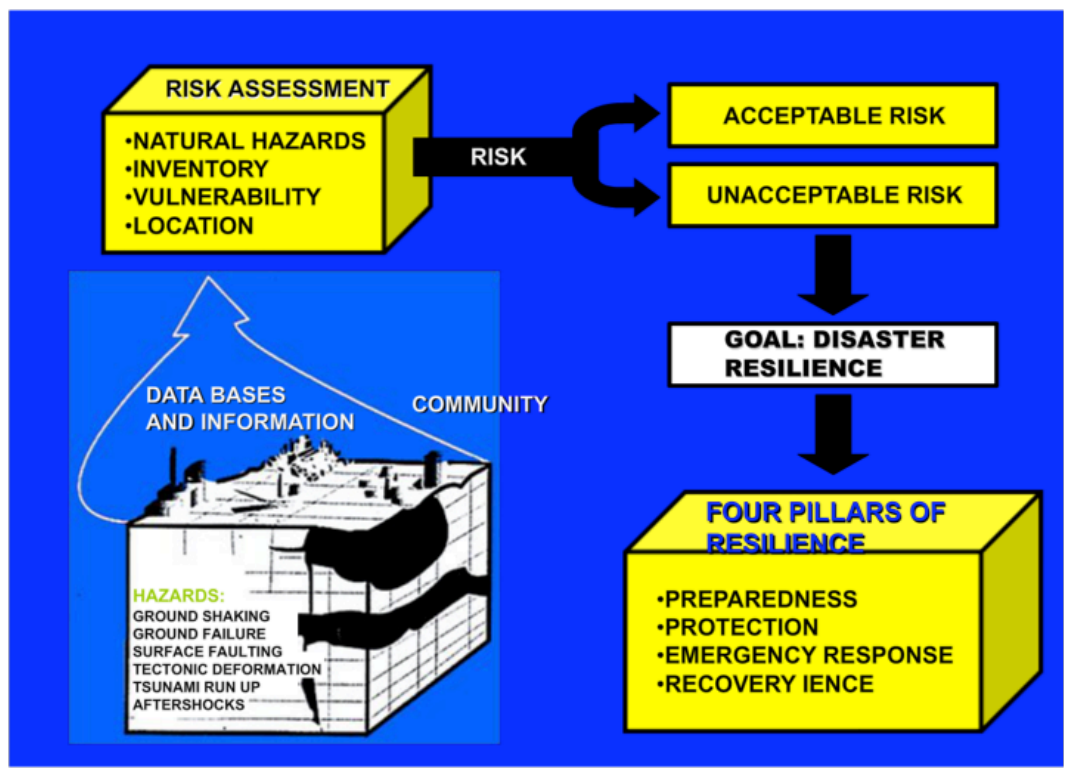

Fig. (3). Disaster resilience as an interaction between hazard, risk, resilience and sustainability (www.google/powershow.com/ disaster recovery a pillar of disaster resilience).

Table 2. PGA values for Merida for two different earthquake design level [11].

\begin{tabular}{|c|c|c|c|c|}
\hline Return Period & $\begin{array}{c}\text { Annual Frequency of } \\
\text { Exceedance }\end{array}$ & $\begin{array}{c}\text { PGA } \\
\text { (Bendito } \text { et al. 2001) }\end{array}$ & $\begin{array}{c}\text { PGA Mean } \\
\text { (ShakeMap) }\end{array}$ & $\begin{array}{c}\text { Magnitude } \\
\text { (M) }\end{array}$ \\
\hline \hline 475 years & 0.00211 & 0.37 & 0.36 & 7.5 \\
\hline 970 years & 0.00105 & 0.46 & 0.47 & 7.7 \\
\hline
\end{tabular}

limited number of well defined fault systems. For these regions, it is considered more appropriate to determine $\mathrm{MCE}_{\mathrm{R}}$ ground motions directly by deterministic methods based on a conservative estimate of the ground shaking associated with characteristic earthquakes of well defined fault systems" [17].

\subsection{Risk}

The Hyogo Framework for Action (HFA), a global 10year action plan for Disaster Risk Reduction to improve the resilience of nations and communities to disasters, was accepted after 168 Governments met in Hyogo, Japan for the World Conference on Disaster Reduction celebrated in January 2005. The three strategic goals of the HFA include:

1) "The integration of disaster risk reduction into sustainable development policies and planning”.

2) "Development and strengthening of institutions, mechanisms and capacities to build resilience to hazards".

3) "The systematic incorporation of risk reduction approaches into the implementation of emergency preparedness, response and recovery programmes".

In order to achive sustainable development it is necessary a holistic approach that considers hazard, vulnerability, risk and disasters as part of a continuous cycle (Fig. 3).
A seismic risk study was developed for Mérida State in order to be able to estimate the potential losses associated with various earthquake scenarios and inform governments on a long term plan for reducing earthquake disaster risks [11]. Two of the PGA values from Table 1 were compared using Hazus MH 2.1 with a ShakeMap as user supply [18]. Hazus is a comprehensive, GIS-based modeling framework formulated by the Federal Emergency Management Agency (FEMA) in partnership with the National Institute of Building Sciences (NIBS). In Table 2, we can observe very similar values between both PGA values for rare and very rare return periods, and suggests a good calibration of Hazus for Mérida State.

Hazus estimates that the largest damage will be produced on the residential structures, which are largely Unreinforced Masonry construction (URM), followed by concrete building types (Concrete Moment Frame (C1), Concrete Shear Walls (C2), Precast Concrete Frames with Concrete Shear Walls (PC2)). In Mérida State $70 \%$ of the residential building stock are built of URM (mostly self-construction) and 30\% of concrete. Some of the results from the risk study are presented on Figs. (4 and 5). These figures present the residential and non-residential loss ratio for two of the many possible scenarios, demonstrating higher loss ratios for residential occupancy types.

Reducing risk or building resilience to disasters is a sustainability requirement, thus a mayor goal for society and highlighted as a strategic goal in the HFA. 


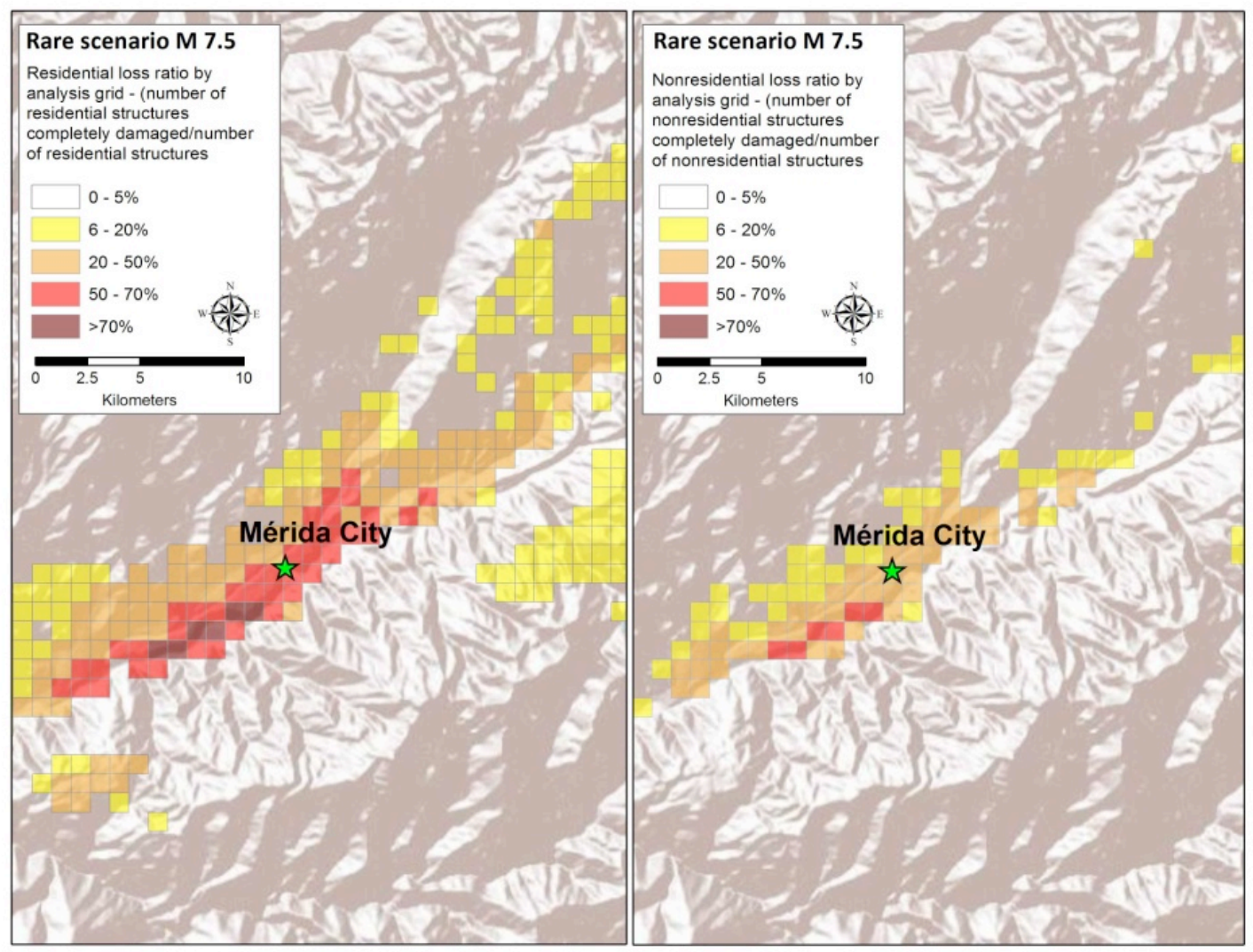

Fig. (4). Residential (left) and nonresidential (right) loss ratio in Mérida State for return period of 475 years scenario [11].

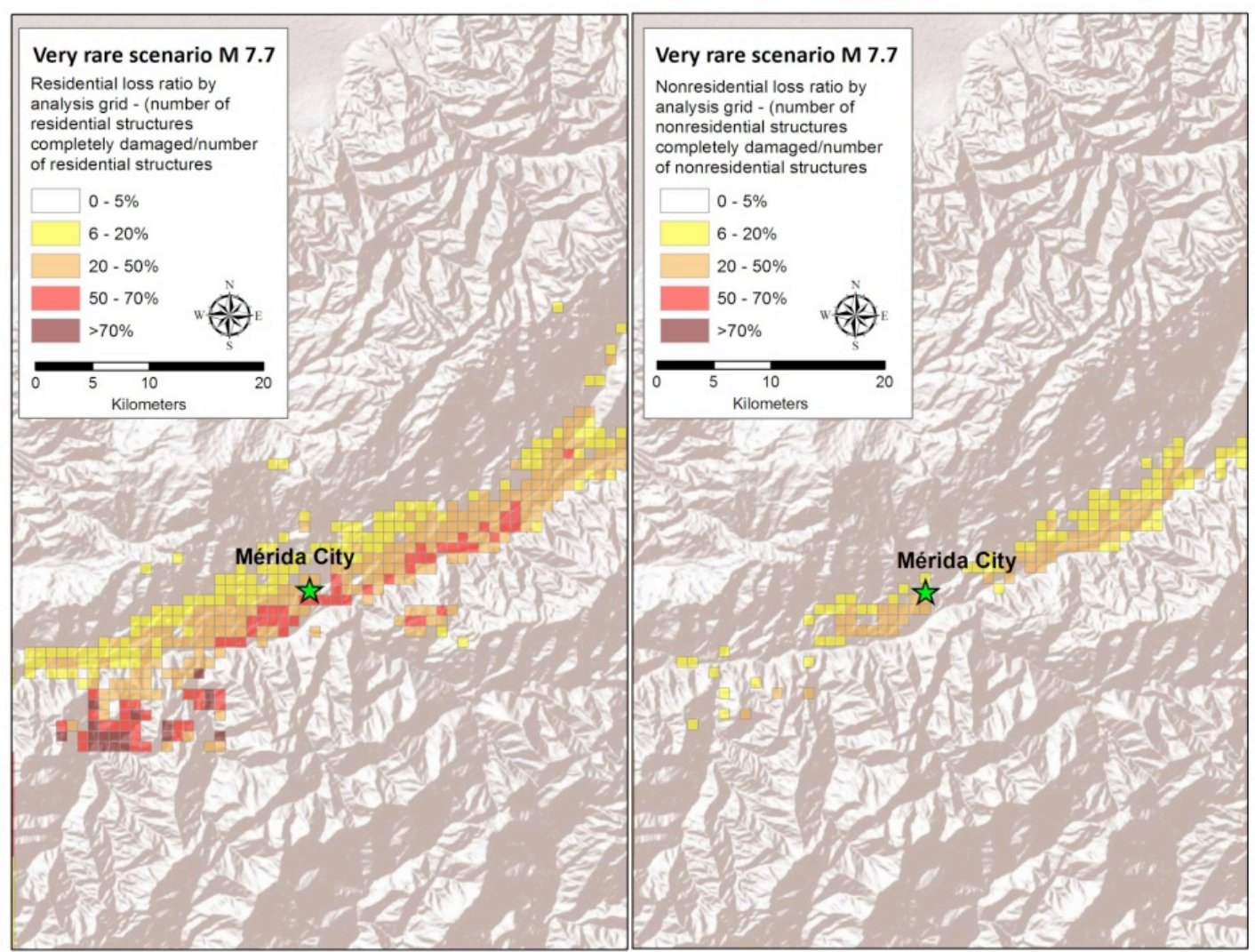

Fig. (5). Residential (left) and nonresidential (right) loss ratio in Mérida State for return period of 970 years scenario [11]. 

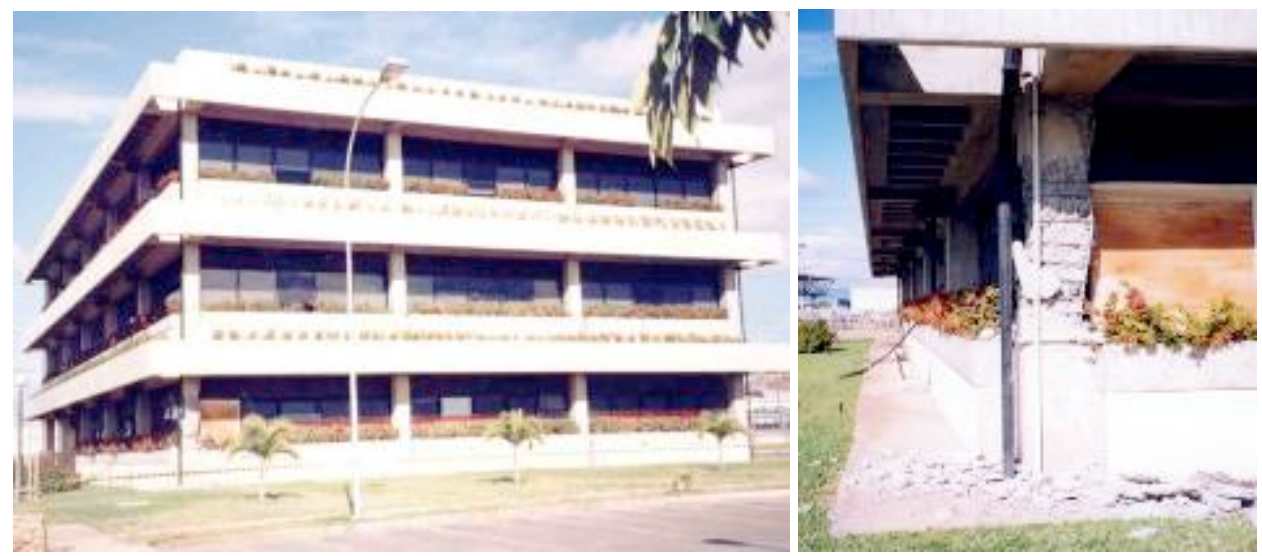

Fig. (6). Effect of short column generated by walls of reinforced concrete. (Photo courtesy of A.Urich).

"The findings of this study are based on an important assumption: the seismic vulnerability and fragility relationships embedded in Hazus for unreinforced masonry and for the nonductile concrete frame buildings are truly representative of building types in Mérida State of Venezuela" [11].

\subsection{Resilience and Sustainability}

The fundamental concept of ductile behavior (well explained by the ductile chain analogy formulated by the professors Pauley and Priestley [19]) has been integrated and improved in the new holistic concepts of resilience and sustainability. For example [20] present a conceptual framework which defines the seismic resilience of communities. This framework relies on seismic resilience structures that will permit "Reduced failure probabilities", "Reduced consequences from failures", and "Reduced time to recovery". The framework also includes quantitative measures of the "ends" of robustness and rapidity, and the "means" of resourcefulness and redundancy.

Seismic sustainability is defined in [21] as the system's capacity to survive any important seismic event without significant repairs or replacement, and is analyzed for different steel-framed structures in terms of four parameters (damage to floor slabs, permanent displacement, feasibility of replacement of members, and inter-storey drift damage).

Consistent with current concepts of sustainability and resilience is the use of a mechanisms playing a "fuse" role, that is clearly taking into account the vulnerability. These mechanisms include the quantification of the hazard (considering the response of the soil), aspects of construction, inspection and maintenance of the building and the integrity of the main components sacrificing other members ("fuses") who are responsible to dissipate the seismic energy. "The sacrificial elements should be easily replaceable, allowing the rest of the structure (that remained elastic) to return to its plumb condition after the "fuses" are removed" [22].

\section{BUILDING PERFORMANCE VS. BUILDING CODES}

A dramatic contrast in building performance and community resilience has been highlighted in two recent disaster. The earthquake in Haiti in January, 2010 resulted in over 220,000 people losing their lives and more than 300,000 being injured [23]. This earthquake released nearly 1,000 times less energy than the earthquake in Chile which occurred 30 days after which also affected a densely populated zone but with 1,000 times fewer victims.

One of the most seismically active zones in the world are the coastal ranges of Chile. "On average, one major earthquake of magnitude 8 has occurred every 10 years in historical times, and most of the individual segments of the coastal ranges have been the site of at least one magnitude 8 during the last 130 years" [24]. Until recently, the Chilean design code did not require confinement in the wall due to the satisfactory performance of buildings during previous earthquakes. Latest design codes, however, require walls to be designed as special structural walls making them less vulnerable. However, a code error in the classification of soils led to the collapse of some buildings in the last strong earthquake [25].

Codes must move from a passive to a proactive posture and use the past as a guide, including lessons learned from past disasters about the resistance of buildings to specific hazards, given the dynamic nature of our planet [26]. Engineering professional must also have a proactive stance rather than just post disaster actions. For example lessons learned during past earthquakes have allowed us to recognize as dangerous a number of design factors in buildings in seismic areas for example: short-column effect; absence of walls; incorporation of the stairs as seismic resistent members; and the spread of 'self-construction'.

\subsection{Short-Column Effect}

In case of an earthquake force, movement of foundations, or a thermal expansion, that cause a relative horizontal movement between the base and the top of the column, the height of the column needs to be "free" and able to deform laterally. The short-column effect restricts the ability of all the column to deform laterally by confining part of the column with building components [27, 28].

Fig. (6) shows an example of the effect of short column, corresponding to a building located in Cumaná, Venezuela about $70 \mathrm{~km}$ from the epicenter of the Cariaco Earthquake, M6.9, which occurred in 1997. Here, the severity of damage and the high levels of deformation experienced by the "free" portion of the columns are evidenced [29]. If the short col- 


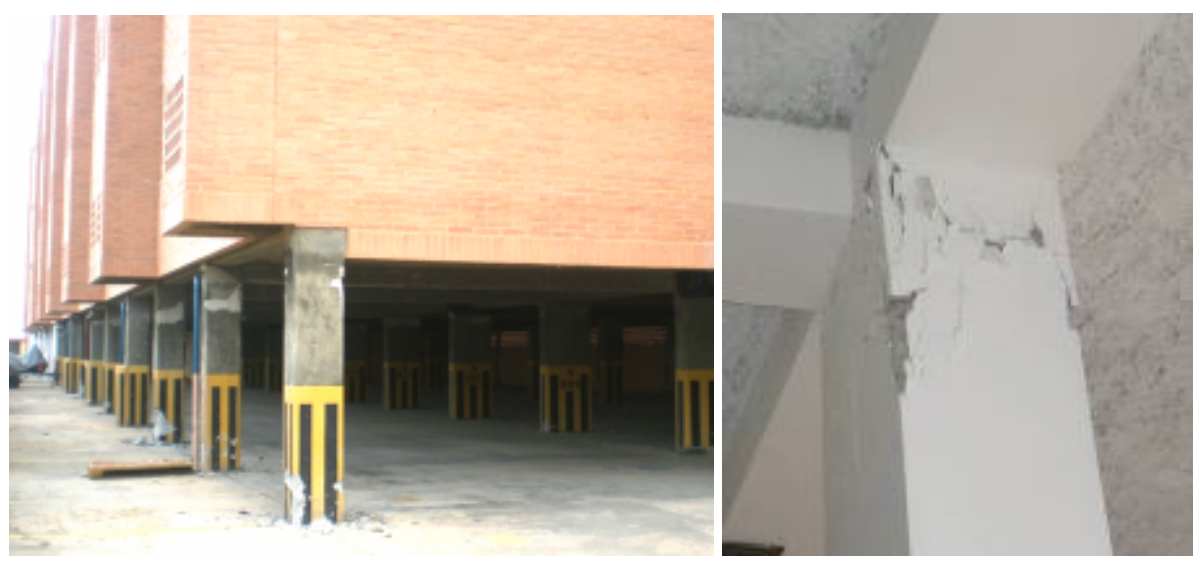

Fig. (7). Story "weak" or "soft" because open space on that first floor. (Photo courtesy of A.Urich).

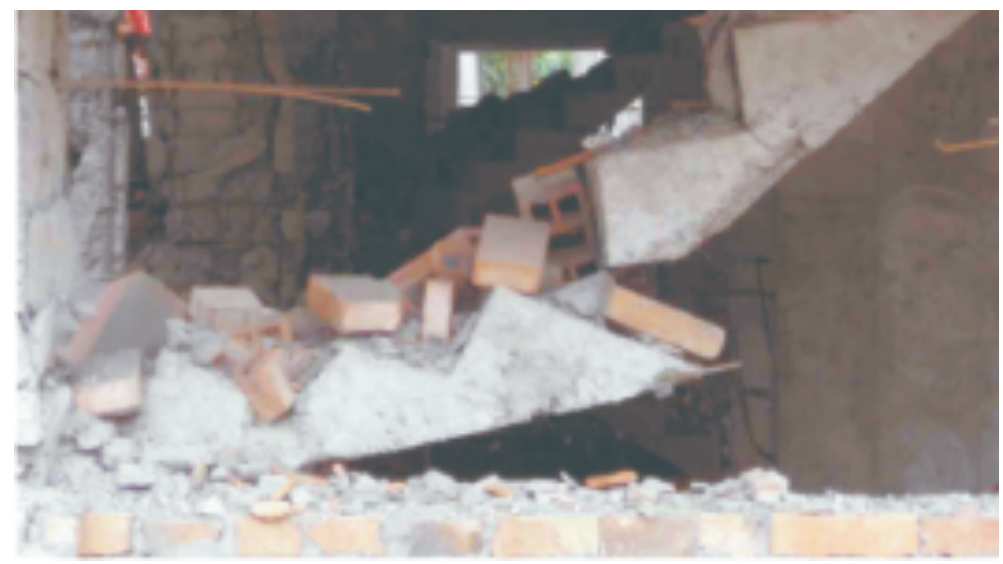

Fig. (8). Complete tread separation from observations after Wenchuan earthquake [32].

umn effect cannot be avoided, it must be included in the structural design and avoid non-intended adjustment to the initial structural configuration [30].

\subsection{Absence of Walls}

Buildings with parking or open commercial space on the first floor have few internal walls, making this storey "weak" or "soft" and likely to collapse during earthquakes. In the ASCE 31 standard for seismic evaluation [31] "a soft storey is a potential safety deficiency and a threat to life". Fig. (7) shows a recent example of the soft-storey mechanism due to the absence of walls on the first floor that occurred in a building located in Tucacas, Venezuela about $50 \mathrm{~km}$ from the epicenter of an earthquake of magnitude M6.2 that occurred on 12 September 2009. In this case, all the columns experienced severe damage by flexo-compression [29].

\subsection{Seismic Vulnerability of Stairs}

We found few publications about the performance of stairs in seismic areas during our review of the literature. Before the 1980's the design of buildings, both in seismic and non-seismic areas, did not consider the presence of stairs, although stairs offer a higher strength and stiffness thereby influencing considerably the distribution of seismic forces. Architects and structural engineers must incorporate stairs as seismic resistent members and capable of affecting the behavior of the entire building. The design and construction should take into account, in addition to the vertical load, those generated by the seismic action [32]. Fig. (8) shows failure on stairs after the Wenchuan, China earthquake.

\subsection{Self-Construction}

While it is not feasible to prevent self-construction, effective guidelines should be developed and implemented as simple building technologies for improved seismic resistance in self-constructed buildings.

One of the most destructive earthquakes has been the M7.0 earthquake that struck Haiti on 12 January 2010 [33]. The considerable human losses can be credited to the poor construction practices given the lack of construction codes or regulations [34], and the largely poor quality of the infrastructure. Following the historic pattern of earthquakes in Haiti, another damaging earthquake could occur at any time. "Reconstruction must therefore be based on sound, simple, and cost-effective engineering practice for all possible natural hazards and well communicated to civil society in Haiti [33].

Every country should not only have building codes, it should also be mandatory that they are used. After the M7.3 earthquake on 2 September 2009 in the south coast of West Java, Indonesia, the majority of the structures damaged were not built following the building codes and construction guidelines [35]. The same bad practice has been observed in East and Central African countries were two important buildings collapsed between March and May 2013 [36]. A special 


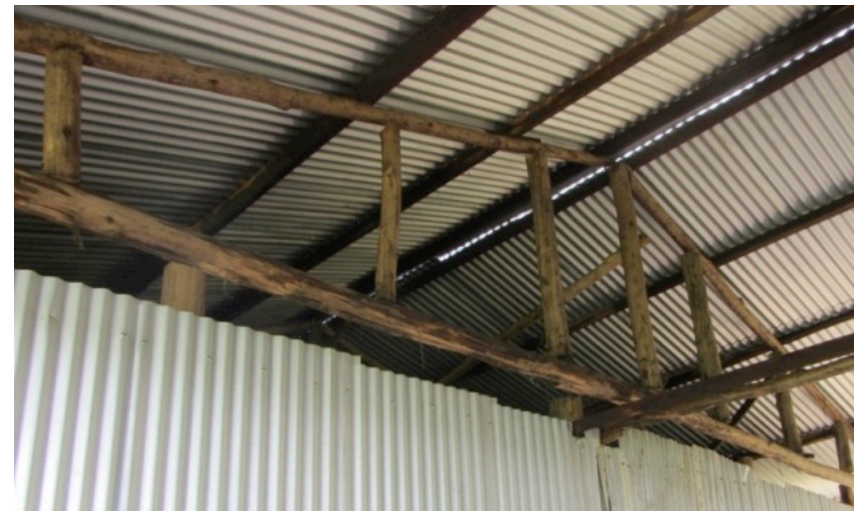

Fig. (9). Timber roof truss forming squares instead of triangles and without longitudinal bracing to prevent the truss from tipping which will drag the other trusses. Source: [36].

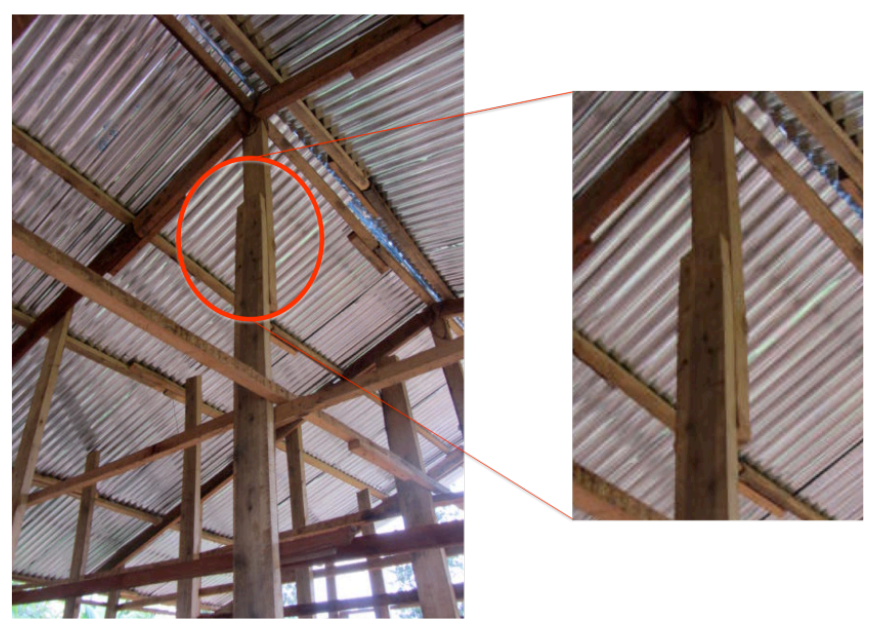

Fig. (10). Use of connectors in places not recommended. Source: [36].

effort is required to motivate engineers, contractors, construction workers to build and rebuild using appropriate construction guidelines and avoid self-constrution.

Self-construction in rural areas can also have important unexpected consequences in food security. For example in Rwanda post-harvest losses are acknowledged as one of the largest sources of inefficiency in agricultural production, "nevertheless, self-construction is a common practice for the post-harvest facilities all over Rwanda" [36]. Some of the errors and deficiencies observed in the post-harvest facilities visited in Rwanda can be observed in Figs. (9 and 10).

\section{DISCUSSIONS AND RECOMMENDATIONS}

The complementary nature of local and technical knowledge could foster the development of participatory approaches that increase the relevance, credibility and legitimacy of co-developed solutions [37] to local construction challenges. A participatory assessment methodology that integrates local and technical knowledge and experience could be part of this effort. For instance, the methodology should contain: 1) best construction practice details so local engineers, contractors, the construction workers, masons, carpenters, and bar benders can understand the building performance during a disaster (earthquake, flood, hurricane, etc...). Once understanding the notion of building performance it is easier to avoid construction errors (irregularities, absence of ring beams, etc...), 2) guidelines on how to identify and rank buildings that are potentially at risk from a natural hazard, 3) capacity building workshops for local engineers, contractors, the construction workers, masons, carpenters, and bar benders, and careful overall management of the process. This methodological approach could contribute to the long term capacity building required to make cities more resilient. "We need to build communities with the confidence that climate change and resulting natural disaster risk are fully considered. It is safer, as well as more costeffective, to construct climate change resistant buildings at the initial stage following relevant building code" [36].

If we can build a strong interdependence of academia, industry, government and civil society the next generation will be more sensitive to societal needs [38].

Universities should improve undergraduate engineering education, and new curriculums should incorporate courses on hazard resistance for undergraduate students. Undergraduate students generally have the knowledge and concepts but they are not taught on how to link them with reality. Universities tend to focus hazard-related building performance more at the level of postgraduate students. And the courses tend to adhere to more traditional programmes, more focused on the design of the structural members, than adopting an integrated approach.

The institutions responsible for the development and updating of building codes need to make greater efforts to the publicity of changes to the construction guidelines and codes. This publicity could make use of professional associations as a communications network [39].

Despite the existence of a list of codes and guidelines for nonengineering construction we believe one of the main reasons why there are not followed correctly and taken into account is because the local engineers, contractors, the construction workers, masons, carpenters, and bar benders have limited understanding of the performance of the buildings. We need to enhance the overall understanding, the capacities, and skills in order to design and construct safe structures, and to spread this knowledge widely and break the vicious cycle of recurrent disaster.

\section{CONFLICT OF INTEREST}

The authors confirm that this article content has no conflict of interest.

\section{ACKNOWLEDGEMENTS}

Declared none.

\section{REFERENCES}

[1] J. C. Gaillard, B. Wisner, D. Benouar, T. Cannon, L. CretonCazanave, J. Dekens, M. Fordham, C. Gilbert, K. Hewitt, I. Kelman, A. Lavell, J. Morin, A. N'Diaye, P. O'Keefe, A. Oliver-Smith, C. Quesada, S. Revet, K. Sudmeier-Rieux, P. Texier, and C. Vallette, "Alternatives for sustained disaster risk reduction," Geography and Environmental Studies Faculty Publications, Paper 16 March 2010. [Online]. Available: http://scholars.wlu.ca/geog faculty/16 [Accessed Sept. 5, 2014]. 
[2] United Nations Development Programme, "Paving the way for climate-resilient infrastructure," International Conference: Strategies for Adapting Public and Private Infrastracture to Climate Change, 30 June 2010. San Salvador, El Salvador.

[3] UNISDR, "Local progress report on the implementation of the Hyogo framework for action and 10 essentials for making cities resilient". Durban, South Africa, 2011. [Online]. Available: http://preventionweb.net/go/31663 [Accessed March 5, 2014].

[4] UNEP, "Keeping Track of Adaptation Actions in Africa. Targeted Fiscal Stimulus Actions Making a Difference". United Nations Environment Programme, Nairobi, 2014.

[5] R. Chambers, Rural Development: Putting the Last First, London: Longmans. 1983. [Online]. Available: http://www.community health [Accessed June 5, 2013].

[6] B. Wisner, "Assessment of capability and vulnerability," In: G. Bankoff, G. Frerks, and T. Hilhorst (Eds), Mapping Vulnerability: Disasters, Development and People, London: Earthscan, June 2004, pp. 183-193, 2004.

[7] J. D. Silva, "Lessons from Aceh: key considerations in postdisaster reconstruction," ARUP, 2010. [Online]. Available: www.dec.org.uk [Accessed May 5, 2013].

[8] W. Lobo-Quintero, "Perfomance, risk, resilience and sustainabilty," Revista Internacional de Ingeniería de Estructuras, Quito, Ecuador, vol. 13 no. 14, pp. 55-86, June 2009.

[9] T. Y. Yang, B. Stojadinovic, and J. Moehle, "Demonstration of a Practical Method for Seismic Performance Assessment of Structural Systems", Earthquake Spectra, vol. 28, no. 2, pp. 811-829, 2012.

[10] A. Bendito, P. Rivero, and W. Lobo-Quintero, "Isoaceleration curves for structural performance levels in western Venezuela," (Curvas de Isoaceleración para Estados de Desempeño Estructural en el Occidente de Venezuela), Boletín Técnico del Instituto de Materiales y Modelos Estructurales (IMME), Venezuela, vol. 39, no. 2, pp. 1-18 (in Spanish), 2001.

[11] A. Bendito, J. Rozelle, and D. Bausch, "Assessing potential earthquake loss in mérida state, venezuela using hazus," International Journal of Disaster Risk Science, vol. 5, no. 3, pp. 176-191, Sep. 2014. DOI: 10.1007/s13753-014-0027-0.

[12] J. Laffaille, F. Audemard, and M. Alvarado, "San Antonio de Mucuño, Mérida Andes, Venezuela: Relocation of a doctrine town following the 1674 earthquake," The Geological Society of America, Special Paper 471, 2010.

[13] R. Altez, "The 1812 disaster in Venezuela, earthquakes, vulnerabilities and a country not that dumb," (El desastre de 1812 en Venezuela, sismos, vulnerabilidades y una patria no tan boba), Universidad Católica Andrés Bello. Fundación de Empresas Polar, Caracas, Venezuela, Special paper, 2006.

[14] R. Altez, "1812 documents for the study of a disaster," (1812 Documentos para el estudio de un desastre). Colección Bicentenario de la Independencia. Academia Nacional de la Historia, Caracas, Venezuela, 2009.

[15] A. Fusell, "Rebuiilding New Zealand's post-seismic Chrischurt: it's all about damage control," In: AISC NASCC 2014 Conference, Toronto, Presentation N23, 2014.

[16] Earthquake Spectra, "Special issue on the next generation attenuation project". Earthquake Spectra, EERI, PEERC and California Department of Transportation, Oakland, California, vol. 24, pp. 1341, Sep. 2008.

[17] J. Grases, and A. Gutiérrez, "Update Venezuelan codes for earthquake resistant design of structures and facilities," (Actualización de la normativa venezolana para el proyecto sismo-resistente de estructuras e instalaciones) Submitted to: el Boletin de la Academia Nacional de la Ingeniería y el Hábitat, Caracas, Venezuela, 2014.

[18] NIBS (National Institute of Building Science). HAZUS ${ }^{M H}$ Technical Manual., Washington, DC: Federal Emergency Management Agency (FEMA), 2012.
[19] T. Paulay, and M. Priestley, Seismic Design of Reinforced Concrete and Masonry Buildings, Wiley Interscience Publication: USA, 1992.

[20] M. Bruneau, and A. Reinhorn, Seismic resilience of communities Conceptualization and operationalization, Multidisciplinary Center for Earthquake Engineering Research, MCEER, University of Buffalo: Buffalo, N.Y, 2003.

[21] J. C. Golondrino, G. A. MacRae, J. Chase, G. W. Rodgers, and C. G. Clifton, "Methodology for quantifying seismic sustainability of steel framed structures," Metodologia para la cuantificación de la sustentabilidad sísmica de estructuras de marco de acero. Traducción autorizada por los autores de un trabajo presentado en STESSA 2012, www.construccionenacero.com ; Boletin Alacero, Abril 2013.

[22] M. Bruneau, S. El-Bahey, S. Fujikura, and D. Keller, "Structural fuses and concrete-filled steel shapes for seismic and multi-hazard resistant design," In: New Zealand Society for Earthquake Engineering Technical Conference and AGM, Wellington-New Zealand, March 26 - 28, 2010

[23] EERI (Earthquake Engineering Research Institute), "Special Earthquake Report, Learning from earthquakes, The Mw 7.0 Haiti Earthquake of January 12, 2010: Report \#2, 2010.

[24] J. C. Ruegg, J. Campos, R. Madariaga, E. Kausel, J. B. de Chabalier, R. Armijo, D. Dimitrov, I. Georgiev, and S. Barrientos, "Interseismic strain accumulations in south central Chile from GPS measurement 1996-1999," Geophysical Reseach Letters, vol. 29, no. 11 , pp. 12-1 to $12-4,2002$.

[25] A. Briceño and N. Carreras, "Analysis and Design of Structural Concrete Walls Considering the Experiences of the Earthquakes in Chile 2010, and New Zealand 2011," (Análisis y diseño de muros estructurales de concreto considerando las experiencias de los terremotos de Chile 2010 y Nueva Zelanda 2011). Degree work submitted as partial requirement for obtaining a civil engineering degree from the Faculty of Engineering Universidad Católica "Andrés Bello", Caracas, Venezuela. 2013.

[26] M. Gilmor, R. Tremblay, and R. Vicent, "Whats's up in the next edition and its seimic provisions," In: AISC NASCC 2014, Toronto Online Conference Proceeding N53, CSA-S16-14, Toronto, 2014.

[27] T. Guevara, and L. García, "The captive-and short-column effects," Earthquake Spectra, vol. 2, no. 1, pp. 141-160, 2005.

[28] J. L. Beauperthuy, and A. Urich, "The effect of short-column. Case studies," (El efecto de columna corta. Estudio de casos), In: IV CONPAT Nacional Conference, Barquisimeto, March 2011.

[29] A. Urich, and J. L. Beauperthuy, "Protagonism of the infill walls on seismic perfomance of Venezuela buildings," In: 15 Word Conference on Earthquake Engineering, Paper 4518, Lisbon, 2012.

[30] A. J. Malaver, and D. R. Rodríguez, "Seismic retrofitting of concrete building damaged by Tucacas earthquake, Venezuela," In: 15 Word Conference on Earthquake Engineering, Paper 2481, Lisbon, 2012.

[31] ASCE, Seismic Evaluation of Existing Buildings, (ASCE/SEI 3103). American Society of Civil Engineers, 2003.

[32] A. Gutiérrez, "Concrete stairs," (Escaleras de concreto), Acero al Día No. 142, Año 13, Octubre 2010, 4p. Gerencia de Mercadeo y Ventas, Sidetur, Caracas, Venezuela.

[33] USGS/EERI, “The Mw 7.0 Haiti Earthquake of January 12, 2010," Advance Reconnaissance Team Report V. 1.1, 2010.

[34] O. Arup, and Partners, "Haiti Earthquake Response," Oxfam GB, Arup Assignment Report, Job number 212323-00. London: Ove Arup and Partners Ltd, 2010.

[35] "Learning from earthquakes the M7.3 September 2, 2009, West Java Quake", EERI Special Earthquake Report, Earthquake engineering research institute, 2009.

[36] A. Bendito, and S. Twomlow, "Promoting climate-smart approaches to post-harvest challenges in Rwanda," International Journal of Agricultural Sustainability, 2014. DOI:10.1080/ 14735903.2014.959329.

[37] E. Barrios, H. Coutinho, and C. A. Medeiros, “InPaC-S: Participatory Knowledge Integration on Indicators of Soil Quality Methodological Guide," ICRAF, Embrapa, CIAT, Nairobi, p. 178, 2012. 
[38] C. Juma, Reinventing African Economies. Technological Innovation and the Sustainability Transition, The Royal Academy of Engineering: London, UK, 2006.
[39] A. Gutiérrez, "Design and behavior of steel structures according to AISC standard," Course Notes, (Proyecto y comportamiento de estructuras de acero según la norma AISC. Notas de curso), Caracas: Venezuela, 2014.

(C) Bendito and Guitérrez; Licensee Bentham Open

This is an open access article licensed under the terms of the Creative Commons Attribution Non-Commercial License (http://creativecommons.org/licenses/ by-nc/3.0/) which permits unrestricted, non-commercial use, distribution and reproduction in any medium, provided the work is properly cited. 